\title{
Infectious diseases and chronic care in Africa
}

\author{
James K Tumwine
}

\section{DOI: http://dx.doi.org/10.4314/ahs.v15i2.2}

Welcome to this June issue of African Health Sciences that is another bumper harvest because of a backlog that we are trying to clear at AHS.

We bring you very interesting manuscripts on infectious diseases particularly hepatitis ${ }^{1,2}$; HIV AIDS ${ }^{3,4}$ and H1N1 Influenza $A$ virus ${ }^{5}$ in the context of chronic care in Africa. Burkina Faso researchers report on the diagnostic performance and operational characteristics of four rapid immune-chromatographic syphilis tests ${ }^{6}$ while Ethiopian scientists report on risk factors for multidrug resistant tuberculosis patients. ${ }^{7}$ Keeping with the TB theme we have work from Angola on emotional distress among patients with tuberculosis ${ }^{8}$. In a similar study Sudanese workers give an insight into illness perceptions and quality of life among tuberculosis patients in Gezira?.

Now parasites! Pakistani workers report on prevalence of Giardia intestinalis and Hymenolepis nana in Afghan refugee population of Mianwali district, Pakistan ${ }^{10}$. This is followed by three articles on malaria. ${ }^{11,12,13}$

To break the infectious disease theme we introduce several articles on pain, trauma and arthritis. ${ }^{14,15,16,17,18,19,20,21}$. We climax our non-communicable disease (NCD) themes with many articles on diabetes mellitus, rightly so, because this has become such an important disorder in Africa contrary to predictions in the pre-independence colonial era $22,23,24,25$. This is followed by reproductive health issues ${ }^{26,27,28,29,30}$, oncology ${ }^{31,32,33,34}$, herbal medicine $^{35,36,37}$, sleep quality ${ }^{38}$ and anthropology ${ }^{39}$. The next set of papers include: lead toxicity ${ }^{40}$, retinol ${ }^{41}$, educational audit ${ }^{42}$ and microbiolog $y^{43}$.

We conclude the review with a relook at chronic care ${ }^{44}$, medical ethics in Africa ${ }^{45}$, alpha thalassemia ${ }^{46}$, asthma ${ }^{47}$, miliary $\mathrm{TB}^{48}$ and cortical blindness preceded by pre-eclampsia ${ }^{49}$. Have enjoyable reading!

\section{References}

1. Baseke J, Musenero M, Mayanja-Kizza H. Prevalence of Hepatitis B and C and relationship to liver disease in HIV infected patients attending Joint Clinical Research Centre Clinic (JCRC),Kampala, Uganda. Afri Health Sci. 2015; 15(2):322-327.
2. Ocama P, Seremba E, Apica B, Opio K. Hepatitis $\mathrm{b}$ and HIV co-infection is still treated using lamivudine-only antiretroviral therapy combination in Uganda. Afri Health Sci. 2015; 15(2):328-333.

3. Bipath P, Levay P, Olorunju S, Viljoen M. A non-specific biomarker of disease activity in HIV/AIDS patients from resource-limited environments. Afri Health Sci. 2015; 15(2):334-343.

4. Namasopo-Oleja M S, Bagenda D, Ekirapa-Kiracho E. Factors affecting disclosure of serostatus to children attending jinja hospital paediatric HIV Clinic, Uganda. Afri Health Sci. 2015; 15(2):344-351.

5. Girgin Nermin K, Remzi I, Zeynep A, Ilker C, Torlar Meltem O, Guven O, et al. A retrospective evaluation of critically ill patients infected with H1N1 Influenza A virus in Bursa, Turkey during the 2009-2010 pandemic - Afri Health Sci. 2015; 15(2):352-359.

6. Bocoum FY, Ouédraogo H, Grissoum T, Kiba A, Tiendrebeogo S, Bationo F, et al. Evaluation of the diagnostic performance and operational characteristics of four rapid immunochromatographic syphilis tests in Burkina Faso. Afri Health Sci. 2015; 15(2):360-367.

7. Mulu W, Nigus D, Mulat M, Aschalew T, Bayeh A. Risk factors for multi-drug resistant tuberculosis patients in Amhara National Regional State. Afri Health Sci. 2015; 15(2):368-377.

8. Benvinda XP, Bruno P. Emotional distress in Angolan patients with several types of tuberculosis. Afri Health Sci. 2015; 15(2):378-384.

9. Mohammed S, Nagla S, Morten S, Asma E, Arja A. Illness perceptions and quality of life among tuberculosis patients in Gezira, Sudan. Afri Health Sci. 2015; 15(2):385-393.

10. Ul Haq KA, Gul NA, Hammad HM, Bibi Y, Bibi A, Mohsan J. Prevalence of Giardia intestinalis and Hymenolepis nana in Afghan refugee population of Mianwali district, Pakistan. Afri Health Sci. 2015; 15(2):394-400.

11. Musoke D, Karani G, Ssempebwa CJ, Etajak S, Guwatudde D, Musoke MB. Knowledge and practices on malaria prevention in two rural communities in Wakiso District, Uganda. Afri Health Sci. 2015; 15(2):401-412.

12. Choonara S, Obby OC, Elwange B. Factors influencing the usage of different types of malaria prevention methods during pregnancy in Kenya. Afri Health Sci. 2015; 15(2):413-419.

13. Oyeyemi A, Ogunnowo B, Odukoya O. Response 
of patent medicine vendors in rural areas of Lagos 26. Rehana AS, Bushra S, Sadia S, Jai KD, Noel MZ, tate Nigeria to antimalarial policy change. Afri Helth Solon PR, et al. Maternal nutrition: how is Eastern a Sci. 2015; 15(2):420-428.

14. Adegoke B, Odole A, Adeyinka A. Adolescent low back pain among secondary school students in Ibadan, Nigeria. Afri Health Sci. 2015; 15(2):429-437.

15. Sharif T, Bugo J. A report from the first regional pain medicine symposia in East, Central and Southern African Region (ECSA-R)-“The Rhino Model in Pain Education in Africa" 14-18 November 2011. Afri Health Sci. 2015; 15(2):438-443.

16. Abledu JK, Offei EB. Musculoskeletal disorder among first-year Ghanaian students in a nursing college Afri Health Sci. 2015; 15(2):444-449.

17. Verusia C, Tanuja D, Simira M, Sarisha M, Varuna S, Ursula K, et al. Satisfaction and adherence of patients with amputations to physiotherapy service at public hospitals in KwaZulu-Natal, South Africa. Afri Health Sci. 2015; 15(2):450-456.

18. Makama J, Iribhogbe P, Ameh E. Overcrowding of accident \& emergency units: is it a growing concern in Nigeria? Afri Health Sci. 2015. 2015; 15(2):457-465.

19. Mung'ayi V, Mbaya K, Sharif T, Kamya D. A randomized controlled trial comparing haemodynamic stability in elderly patients undergoing spinal anaesthesia at L5, S1 versus spinal anaesthesia at L3, 4 at a tertiary African hospital. . Afri Health Sci. 2015; 15(2):466-479. 20. Adejugbagbe AM, Ayoola FA, Rukewe A, Alonge T. Epidemiology of road traffic crashes among long distance drivers in Ibadan, Nigeria. Afri Health Sci 2015; 15(2):480-488.

21. Fatma E, Bünyamin K, Savas $S$, Mehmet U, Selma $\mathrm{Y}$, Ismail B, et al. Epicardial fat thickness in Patients with rheumatoid arthritis. Afri Health Sci. 2015; 15(2):489 495.

22. Ssenyange WC, Namulindwa A, Oyik B, Ssebulib J. Plants used to manage diabetes mellitus type II in selected districts of Central Uganda. Afri Health Sci. 2015; 15(2):496-502.

23. Osama A-J, Shehab A E-K. Psychological wellbeing and biochemical modulation in response to weight loss in obese type 2 diabetes patients. Afri Health Sci. 2015; 15(2):503-512.

24. Awodele O, Osuolale JA. Medication adherence in type 2 diabetes patients: study of patients in Alimosho general hospital, Igando, Lagos, Nigeria. Afri Health $S_{c i}$ 2015; 15(2):513-522.

25. Mutlu N, Esra H, Begum A, Fatma D, Arzu Y, Yal cin $\mathrm{H}$, et al. Relation of maternal vitamin $\mathrm{D}$ status with gestational diabetes mellitus and perinatal outcome. Afri Health Sci. 2015; 15(2):523-531.

15(2):568-575. 31. Taha MOA, Abdalla AA E, Mohamed RS. Pattern
\& presentation of colorectal cancer in Central Sudan, retrospective descriptive study, 2010-2012. Afri Health Sci. 2015; 15(2):576-580.

32. Anazoeze M, Sunday O, Obike I, Awele C, Kenech M. Comparison of absolute neutrophil to CD4 lymphocyte values as a marker of immunosuppression in cancer patients on cytotoxic chemotherapy. Afri Health Sci. 2015; 15(2):581-589.

33. Liu X, Ni C, Li C, Liu T. Drug-drug interation prediction between ketoconazole and anti-liver cancer drug Gomisin G. Afri Health Sci. 2015; 15(2):590-593. 34. Dongmei G, Dengjun S, Liangming Z, Weiwei Z. The therapy of Gefitinib towards breast cancer partially through reversing breast cancer biomarker arginine. Afri Health Sci. 2015; 15(2):594-597.

35. Naggayi M, Mukiibi N, Iliya E. The protective efacetamol induced nephrotoxicity in male wistar rats Afri Health Sci. 2015; 15(2):598-605.

36. Ladokun O, Ojezele M, Arojojoye O. Comparative study on the effects of aqueous extracts of Viscum album (mistletoe) from three host plants on hematoogical parameters in albino rats. Afri Health Sci. 2015; 15(2):606-612.

37. Maher K, Ali YB, Sofiane B. Anti-inflammatory and antioxidant properties of Eriobotrya japonica leaves extracts. Afri Health Sci. 2015; 15(2):613-620.

38. Murat S, Ali U, Serdal K, Süleyman D, Illknur P, Mehmet $\mathrm{S}$, et al. Assessment of subjective sleep quality in iron deficiency anemia. Afri Health Sci. 2015; 15(2):621 627.

African Health Sciences Vol 15 Issue 2, June 2015
39. Sharif T, Bugo J. The anthropological approach challenges the conventional approach to bioethical dilemmas: a Kenyan Maasai perspective. Afri Health Sa 2015; 15(2):628-633.

40. Liu K-S, Mao X-D, Shi J, Dai C-F, Gu P. Toward biomonitoring of toxic(lead) and essential elements in whole blood from 1- to 72-month old children: a cross-sectional study. Afri Health Sci. 2015; 15(2):634 640.

41. Elom A, Imane E, Kaoutar B, Khalid E, Asmaa E, Mehdi A, et al. Comparison of a fluorometric assay kit with high-performance liquid chromatography for the assessment of serum retinol concentration. Afri Health Sci. 2015; 15(2):641-646.

42. Savage AR. Educational audit on drug dose calcuation learning in a Tanzanian school of nursing. Afri Health Sci. 2015; 15(2):647-655.

43. Adugna A, Kibret M, Abera B, Nibret E, Adal M. Antibiogram of E. coli serotypes isolated from children aged under five with acute diarrhea in Bahir Dar Town Afri Health Sci.2015; 15(2):656-664. fects of aqueous extract of carica papaya seeds in par-
44. Govender P, Jacqui B, Aadila H, Tamryn J, Nazmeera M, Straeuli-Paul D. Life within chronic care: is his a service or sentence? Afri Health Sci. 2015; 15(2): 665-672.

45. Kehinde M, Abdulrasheed N, Tajudeen O, Abdulkabir A. Medical ethics in sub-Sahara Africa: closing the gaps. Afri Health Sci. 2015; 15(2):673-681.

46. Lubega I, Ndugwa CM, Mworozi EA, Tumwine JK. Alpha thalassaemia among sickle cell anaemia patients in Kampala, Uganda. Afri Health Sci. 2015; 15(2):682689.

47. Mosunmola TF. Children with bronchial asthma assessed for psychosocial problems in a teaching hospital in Nigeria. Afri Health Sci.2015; 15(2):690-700.

48. Liu H, Zhao L. Miliary tuberculosis after in vitro fertilization and embryo transplantation. Afri Health Sci. 2015. 2015; 15(2):701-704

4. Wang Y, Cao Q, Zhang L, Zhang S, Shi L, Sha O. Acute cortical blindness caused by pre-eclampsia in the antepartum; posterior reversible encephalopathy syndrome. Afri Health Sci. 2015; 15(2):705-708 